\title{
Evaluation of the Relationship Between ABO/Rh Blood Groups and Severity of Liver Fibrosis in Patients with Chronic Hepatitis $B$
}

\author{
Kronik Hepatit B'li Hastalarda ABO/Rh Kan Grupları ile Karaciğer Fibrozisinin Ciddiyeti Arasındaki \\ Ilișkinin Irdelenmesi
}

\author{
Ismail Necati HAKYEMEZ, Bülent DURDU, Sibel BOLUKÇU, Turan ASLAN
}

Bezmialem Vakif University Faculty of Medicine, Department of Infectious Diseases and Clinical Microbiology, Istanbul, Turkey

\begin{abstract}
Objective: Studies on the severity of fibrosis in chronic viral hepatitis are scarce and limited with only hepatitis $C$ infection. The aim of this study was to determine the role of ABO-Rh blood groups in the severity of fibrosis and progression to cirrhosis in patients with chronic hepatitis B (CHB).

Materials and Methods: This retrospective study was performed in patients who received the diagnosis of $\mathrm{CHB}$ in the infectious diseases clinics at Bezmialem Vakif University Hospital. Age, sex, ABO-Rh blood groups and fibrosis scores of the patients were recorded. The patients were stratified according to severity of fibrosis (F0-2: No fibrosis/mild fibrosis and F3-6: Significant fibrosis) and the presence of cirrhosis (F0-4: No cirrhosis, F5-6: Cirrhosis).

Results: Four hundred one (59.5\%) of 674 patients were male. The median age of the patients was $40( \pm 17.86)$ years. Twentyfive $(3.7 \%)$ of the $171(25.4 \%)$ patients, in whom liver biopsy was performed, the stage of the fibrosis score was $\geq 5$ and, thus, were considered as having cirrhosis. ABO-Rh blood groups distribution in $\mathrm{CHB}$ cases was similar to that in blood donors in our hospital $(p=0.152)$. It was found that $O$ blood group significantly correlated with significant liver fibrosis $(p=0.008)$ and the presence of cirrhosis $(p=0.007)$. In addition, Rh positivity appeared to be related with the presence of cirrhosis $(p=0.037)$.

Conclusion: $O$ blood group may probably be involved in significant fibrosis and progression to cirrhosis as a host genetic factor in $\mathrm{CHB}$. Keywords: $A B O$ blood group, chronic hepatitis B, liver fibrosis, cirrhosis
\end{abstract}

öz

Amaç: Kronik viral hepatitlerde fibrozis ciddiyeti ilişkili çalışmalar hepatit $C$ enfeksiyonu ile sınırı olmak üzere çok azdır. Bu çalışmanın amacl, ABO-Rh kan gruplarının kronik hepatit B (KHB) hastalarında fibrozis şiddeti ve siroza gidişte rolünü saptamaktır.

Gereç ve Yöntemler: Bu çalışma Bezmialem Vakıf Üniversitesi Hastanesi Enfeksiyon Hastalıkları Kliniği'nde KHB tanısı alan hastalar arasında retrospektif olarak gerçekleştirilmiştir. Yaş, cinsiyet, ABORh kan grupları ve fibrozis skorlarına ait hasta verileri kaydedilmiştir. Fibrozis ciddiyeti (F0-2: Fibrozis yok/hafif ve F3-6: Önemli fibrozis) ve siroz varlığı (F0-4: Siroz yok, F5-6: Siroz) açısından gruplandırma yapılmıştır.

Bulgular: Çalışmaya alınan 674 olgunun 401'i $(\% 59,5)$ erkek idi. Yaşların ortalaması $40(17,86)$ idi. Karaciğer biyopsisi uygulanan $171(\% 25,4)$ olgunun 25 'i $(\% 3,7)$ fibrosis skoru $\geq 5$ olup karaciğer sirozu kabul edilmiştir. KHB olgularının ABO-Rh kan grubu dağılımı hastanemiz kan bağışçıları verileri ile benzer saptanmıştır $(p>0,05)$. O kan grubu ile önemli karaciğer fibrozisi $(p=0,008)$ ve siroz varlığı $(p=0,007)$ arasında anlamlı korelasyon saptanmıştı. Ayrıca, Rh varlığının ise siroz ile ilişkili olduğu görülmüştür $(p=0,037)$.

Sonuç: O kan grubunun kronik hepatit B'de ileri fibrozis ve siroza gidişte konak genetik faktörü olarak rol oynayabileceği düşünülmektedir.

Anahtar Kelimeler: ABO kan grubu, kronik hepatit B, karaciğer fibrozisi, siroz 


\section{Introduction}

Blood group antigens represent hereditary polymorphic features transmitted between individuals and populations. Currently, 34 human blood group and hundreds of individual blood group antigens are known. Differences in expression of blood group antigens may affect host susceptibility to many infections. Blood groups may be directly involved in infection as a receptors or coreceptors (1). The relationship between ABO blood groups and diseases has always been an area of interest. In the early publications about this issue, cancer, peptic ulcer and thrombotic diseases were claimed to be related with $A B O$ blood groups $(2,3,4)$. Up to now, research on the relationship of $A B O$ blood groups with coronary heart disease, hepatocellular carcinoma (HCC), stomach cancer, pancreatic cancer, acne vulgaris, chronic renal failure (CRF), brucellosis, malaria, Crimean-Congo haemorrhagic fever (CCHF), Helicobacter pylori (H. pylori) infection have been reported in the literature $(5,6,7,8,9,10,11,12,13)$. Chronic hepatitis $B$ virus (HBV) infection ( $\mathrm{CHB}$ ) is still considered as an important public health issue worldwide, despite the existing effective prophylactic vaccine and strong antiviral therapies. Globally 248 million patients are infected with HBV. Seroprevalance of HBV infection in Turkey is $4 \%$ (14). Liver fibrosis, which is a result of processes involved in stimulation of fibrogenesis and arrangement of fibrolysis, may lead to cirrhosis and, thus, has a major role in morbidity and mortality associated with hepatic disease. In the first step, liver fibrosis may be assessed by using experimental serum markers as an alternative to biopsy (15). There are studies showing the relationship between chronic viral hepatitis and blood groups $(16,17)$. However, studies on the stage of fibrosis in chronic viral hepatitis are scarce and limited with only hepatitis $C$ infection (18). Detection of ABO blood groups as a genetic risk factor is recommended during assessment of progression of hepatic fibrosis (19). In literature search, we could not find any study evaluating the stage of fibrosis and presence of cirrhosis in $\mathrm{CHB}$ patients and their relationship with $\mathrm{ABO}$ $\mathrm{Rh}$ blood groups. In this manuscript, we aimed to evaluate the prevalence of $\mathrm{ABO}-\mathrm{Rh}$ blood groups in $\mathrm{CHB}$ patients and the correlation of blood groups with severity of hepatic fibrosis and presence of cirrhosis.

\section{Materials and Methods}

\section{Study Population}

This study was conducted as a retrospective review of the records of patients diagnosed with $\mathrm{CHB}$ in the infectious diseases clinics at Bezmialem Vakıf University (BVU) via hospital information management system. Inclusion criteria were being $\geq 16$ years old, hepatitis B surface antigen ( $\mathrm{HBsAg}$ ) positivity for at least 8 months and a known ABO-Rh blood group. Patients co-infected with hepatitis $\mathrm{C}$ virus (HCV), hepatitis $\mathrm{D}$ virus (HDV) and human immunodeficiency virus (HIV) were excluded from the study. Age, sex, ABO-Rh blood groups and fibrosis score were recorded. The distribution of $\mathrm{ABO}-\mathrm{Rh}$ blood groups among $\mathrm{CHB}$ patients was compared with BVU hospital blood donors (20). The patients were evaluated in two distinct categories: severity of fibrosis (FO-2: No fibrosis/mild fibrosis and F3-6: Significant fibrosis) and presence of cirrhosis (F0-5: No cirrhosis and F5-6: Cirrhosis).

\section{Laboratory Analysis}

ABO-Rh blood groups were determined by the lam agglutination method using blood grouping reagent (Dia-Gast, Loos, France), microplate agglutination method using Galileo System (Stratec, Frankfurt, Germany), or gel centrifugation method using $\mathrm{IH}-1000$ Fully Automated System (DiaMed, Cressier, Switzerland).

\section{Histological Evaluation}

Ultrasound-guided liver biopsy was performed by using a fully automated biopsy needle (18 G BioPinceTM, INTERVMDTech, Gainesville, Florida). Biopsy samples were obtained by using Haematoxylin-Eosin and Masson's Trichrome staining on paraffin-embedded hepatic tissue fixed with formalin. All histological samples were assessed by a pathologist blind to patient characteristics by using Ishak staging scale and scored accordingly.

\section{Statistical Analysis}

Descriptive statistics of continuous numerical variables were expressed as ratio and interval; categorical variables were expressed as frequency distribution and number. The significance of association between ABO-Rh blood groups and significant fibrosis or presence of cirrhosis was assessed by Pearson's Chisquare test. Conformity of continuous variable to normal distribution was assessed by using the one-sample Kolmogorov-Smirnov test. Statistical analysis was performed using SPSS software, version 17. The results were considered statistically significant when the probability of findings occurring by chance was less than $5 \%$ $(p<0.05)$. The study was approved by the BVU Ethics Committee for Clinical Research (20.05.2015/7591)

\section{Results}

\section{Patients' Characteristics and Blood Group Distribution}

Out of 1172 patients who were screened for eligibility, 674 patients were included in the study. Four hundred one patients were male (59.5\%) and 273 were female (40.5\%) and their median age was $40 \pm 17.86$ years. Four hundred ten $(60.8 \%)$ patients were with inactive $\mathrm{CHB}$ and 264 (39.2\%) with active CHB. Liver biopsy was done in 171 (25.4\%) patients. In 25 of them (3.7\%), the stage of fibrosis was $\geq 5$ and, thus, they were considered as having cirrhosis. Cirrhosis was found to be more frequent in males $(n=20$, $\mathrm{p}=0.009$ ). The data about distribution of blood group antigens among $\mathrm{CHB}$ patients and that in BVU hospital blood donors was similar (Table 1) $(x 2=10.68 ; p=0.152)$. When $\mathrm{CHB}$ patients with significant liver fibrosis and cirrhosis were evaluated according to their $\mathrm{ABO}$ blood group antigen status, it was observed that in $\mathrm{O}$ blood group, significant fibrosis and cirrhosis were more frequent than in other blood groups (Table 2) ( $p=0.008, p=0.007)$. Cirrhosis development was found to be more frequent in $\mathrm{Rh}$ antigen-positive patients $(p=0.037)$.

\section{Discussion}

Our study evaluating the correlation of ABO-Rh blood groups with the severity of fibrosis and presence of cirrhosis has shown that such a significant correlation does exist with blood group $\mathrm{O}$. $\mathrm{Rh}$ positivity was observed to be related with cirrhosis. Distribution of $\mathrm{ABO}$ blood groups in $\mathrm{CHB}$ patients was similar to that in healthy blood donors. O blood group may serve as an independent genetic 
risk factor predicting hepatic fibrosis. In their study comprising 346 French patients with a diagnosis of chronic hepatitis $\mathrm{C}(\mathrm{CHC})$, Poujol-Robert et al. (19) have found that the non-O blood group was more common in patients with advanced fibrosis and they have considered this finding as an independent risk factor.

Shavakhi et al. (18) have found a significant association between severe hepatic fibrosis and non-O blood group. In a study focusing on a serum hepatitis epidemic limited to patients and staff of a haemodialysis unit, $\mathrm{O}$ blood group was found to be dominant particularly in severe cases, leading to a suggestion that host factors may be important in the genesis of this disease (21). In another study, HBsAg seroprevalance was the highest in patients with $\mathrm{O}$ blood group among a cohort of 330 blood donors, however, the association was not statistically significant (22). Siransy et al. (23) have found that $\mathrm{O}$ blood group of individuals were infected with HIV and HBV infection more frequently than those with non-O blood group. In a comprehensive study including antenatal screening tests, $B$ and $A B$ blood groups were observed to be associated with increasing HBV infection (24). Behal et al. (16) have determined HCV seropositivity in 68 of 20.000 blood donors and have reported that $\mathrm{HCV}$ seroprevalence was higher in $\mathrm{O}$ blood group and lower in $\mathrm{AB}$ blood group. Omar et al. have compared 12 HBV, $71 \mathrm{HCV}$ and 371 healthy blood donors and found that HBV and HCV seroprevalence was higher in subjects with Rh positivity and in those of $O$ blood group (25). Pourhassan (26) have found no association between $\mathrm{CHB}$ and $\mathrm{ABO}$ blood groups in a study including a cohort comprising 200 patients with CHB, 200 with $\mathrm{CHC}$ and 200 healthy individuals, however, they have observed

Table 1. Distribution of blood groups among chronic hepatitis B patients and the Bezmialem Vakıf University Hospital blood donors

\begin{tabular}{|l|l|l|}
\hline $\begin{array}{l}\text { ABO-Rh } \\
\text { blood groups }\end{array}$ & $\begin{array}{l}\text { CHB patients } \\
\mathbf{n}(\%)\end{array}$ & $\begin{array}{l}\text { BVU blood donors (20) } \\
\mathbf{n}(\%)\end{array}$ \\
\hline A Rh + & $244(36.2)$ & $2305(38.2)$ \\
\hline O Rh + & $218(32.3)$ & $1746(28.9)$ \\
\hline B Rh + & $89(13.2)$ & $744(12.3)$ \\
\hline AB Rh + & $48(7.1)$ & $397(6.6)$ \\
\hline A Rh - & $23(3.4)$ & $319(5.3)$ \\
\hline O Rh - & $30(4.5)$ & $249(4.1)$ \\
\hline B Rh - & $12(1.8)$ & $162(2.7)$ \\
\hline AB Rh - & $10(1.5)$ & $119(1.9)$ \\
\hline Total & $674(100)$ & $6041(100)$ \\
\hline CHB: Chronic hepatitis B, BVU: Bezmialem Vakif University \\
\hline
\end{tabular}

that the rate of $\mathrm{O}$ blood group was significantly higher in $\mathrm{CHC}$ group. Naeini et al. (17) have found no correlation in their study comparing patients $\mathrm{CHB}$ and $\mathrm{CHC}$ and blood donors according to their ABO-Rh blood groups. Exact underlying mechanism for the association between HBV infection and ABO blood groups is not clearly known, but blood groups may affect HBV susceptibility via receptor-mediated binding affinity (27).

ABO blood group antigens, known as first human genetic markers, are complex carbohydrate molecules expressed from red blood cells and other cell lineages and tissues. Increasing evidence indicates that $A B O$ antigens, in addition to their crucial role in transfusion medicine, may have a probable interaction with pathogenesis of many infectious, neoplastic and cardiovascular diseases (28). The risk of cerebral vein thrombosis is higher in non-O blood group individuals (29). Hazendonk et al., (30) in their study evaluating the extent and predictors of underdosing and overdosing in perioperative hemophilia A patients, found that blood $O$ patients had a higher risk of perioperative bleeding complications compared to those with blood group non-O. A synergism between blood group A and HBV infection in the development of extrahepatic cholangiocarcinoma has been suggested (31). In their case-control study including 1.538 patients with newly diagnosed HCC, Shim et al. (6) from Korea have concluded that blood group A and genotype AA showed the highest risk of HCC. In a study of 339.432 individuals conducted in Taiwan, A blood group was found to be associated with increased risk of stomach cancer and non-O blood types with pancreatic cancer (7). Kurt et al. (9) have reported that CRF was less frequent in $0 \mathrm{Rh}(+)$ patients but more frequent in $\mathrm{B} R \mathrm{Rh}(-)$ patients (9). Ansari et al. (13) have found that O blood group is a risk factor in the development of $H$. pylori-associated gastroduodenal disease and ulcer. A blood group has been found to be significantly associated with $\mathrm{CHB}$ and pancreatic cancer and, $\mathrm{B}$ blood group has been found to be significantly associated with ovarian cancer $(27,32)$. It has been found that patients with $\mathrm{O}$ blood groups were more susceptible to gastrointestinal infection epidemic due to Escherichia coli O 157 and mortality was higher among this group (33). It has been reported that $\mathrm{O}$ blood group was prophylactic against malaria (11). In their study, Jang et al. (34) have reviewed 108.898 medical records of $\mathrm{ABO}$ and $\mathrm{HBsAg}$ results and found that blood group A was more prone to have positive results with $\mathrm{HBsAg}$, on the other hand, blood group O was more prone to Clostridium difficile toxin. Güven et al. (12) have reported that in CCHF cases, bleeding tendency was more common in patients with $\mathrm{O}$ blood group. Most of these studies have shown that O blood group may lead to an increase or decrease in susceptibility to certain diseases as a host factor.

Table 2. Correlation of ABO-Rh blood groups with significant fibrosis (F3-6) and the presence of cirrhosis (F5-6)

\begin{tabular}{|c|c|c|c|c|c|c|}
\hline O blood group & $45(26.2)$ & $33(19.2)$ & $* 0.008$ & $59(34.3)$ & $18(10.5)$ & ${ }^{*} 0.007$ \\
\hline B blood group & $19(11)$ & $6(3.5)$ & 0.355 & $23(13.4)$ & $2(1.2)$ & 0.548 \\
\hline
\end{tabular}


The limitations of our study include the absence of any other study criticizing the literature for the correlation between blood groups and liver fibrosis with $\mathrm{CHB}$ to compare our findings in detailed manner, the sampling restrictions duo to absence of any other involved center except our hospital, and to discharge patients with HCV and HDV infection. Briefly, we assume that multicenter studies may be more effective to criticize the relationship between hepatic fibrosis and ABO-Rh blood groups in patients with $\mathrm{CHB}$.

\section{Conclusion}

Our study suggests that $\mathrm{O}$ blood group and $\mathrm{Rh}$ antigen positivity in CHB cases may be a genetic host risk factor for severe hepatic fibrosis and progression to cirrhosis. In order to clarify this assertion, further studies that include larger cohorts are needed.

\section{Ethics}

Ethics Committee Approval: The study was approved by Bezmialem Vakıf University Ethic Committee for Clinical Research (2015/7591), Informed Consent: Written informed consent was obtained from patients who participated in this study.

Peer-review: External and Internal peer-reviewed.

\section{Authorship Contributions}

Surgical and Medical Practices: Ismail Necati Hakyemez, Concept: Ismail Necati Hakyemez, Design: Ismail Necati Hakyemez, Turan Aslan, Data Collection or Processing: Ismail Necati Hakyemez, Bülent Durdu, Analysis or Interpretation: Ismail Necati Hakyemez, Sibel Bolukçu, Bülent Durdu, Literature Search: Ismail Necati Hakyemez, Bülent Durdu, Writing: Ismail Necati Hakyemez, Language Editing: Turan Aslan.

Conflict of Interest: No conflict of interest was declared by the authors.

Financial Disclosure: The authors declared that this study received no financial support.

Hakyemez IN, Durdu B, Bolukçu S, Aslan T. Evaluation of the Relationship Between ABO/Rh Blood Groups and Severity of Liver Fibrosis in Patients With Chronic Hepatitis B. Viral Hepatitis J 2016;22:23-27.

\section{References}

1. Cooling L. Blood Groups in Infection and Host Susceptibility. Clin Microbiol Rev. 2015;28:801-870.

2. Roberts JA. The relationship of the $A B O$ blood groups to cancer Acta Unio Int Contra Cancrum. 1954;10:155-156.

3. Sorensen KH. Peptic ulcer and the ABO blood group system. Dan Med Bull. 1957:4:45-47.

4. Jick $H$, Slone $D$, Westerholm B, Inman WH, Vessey MP, Shapiro $\mathrm{S}$, Lewis GP, Worcester J. Venous thromboembolic disease and ABO blood type. A cooperative study. Lancet 1969;1:539-542.

5. Takagi $\mathrm{H}$, Umemoto $\mathrm{T}$; All-Literature Investigation of Cardiovascular Evidence (ALICE) Group. Meta-analysis of Non-O Blood Group as an independent risk factor for coronary artery disease. Am J Cardiol. 2015;116:699-704.

6. Shim HJ, Lee R, Shin MH, Kim HN, Cho D, Ahn HR, Kweon SS. Association between ABO genotype and risk of hepatocellular carcinoma in Koreans. Asian Pac J Cancer Prev. 2015;16:27712775.

7. Sun $W$, Wen $C P$, Lin J, Wen $C$, Pu X, Huang M, Tsai MK, Tsao CK, Wu X, Chow WH. ABO blood types and cancer risk--a cohort study of 339,432 subjects in Taiwan. Cancer Epidemiol. 2015:39:150-156.

8. Terzi E, Türsen B, Dursun $P$, Erdem T, Türsen Ü. The relationship between $A B O$ blood groups and acne vulgaris. Saudi J Med Med Sci. 2016;4:26-28.

9. Kurt H, Yavuz T, Toprak Ö, Demirkıran D, Sarı Y. The relationship of $\mathrm{ABO}$ Blood groups with chronic renal failure. Eur J Health Sci. 2015;1:109-113.

10. Mohsenpour B, Hajibagheri K, Afrasiabian S, Ghaderi E, Ghasembegloo S. ABO blood groups and susceptibility to brucellosis. Jpn J Infect Dis. 2015;68:124-127.

11. Bedu-Addo G, Gai PP, Meese S, Eggelte TA, Thangaraj K, Mockenhaupt FP. Reduced prevalence of placental malaria in primiparae with blood group O. Malar J. 2014;13:289.

12. Güven AS, Sancakdar E, Kaya A, Uysal EB, Oflaz MB, Bolat F, Karapınar $\mathrm{H}$, Koç $\mathrm{E}$, Icagasioglu FD. Value of $\mathrm{ABO}$ blood group in predicting the severity of children with Crimean-Congo hemorrhagic fever. Int J Clin Exp Med. 2014;7:416-420.

13. Ansari SA, Khan A, Khan TA, Raza Y, Syed SA, Akhtar SS, Kazmi SU. Correlation of $\mathrm{ABH}$ blood group antigens secretion with Helicobacter pylori infection in Pakistani patients. Trop Med Int Health. 2015;20:115-119.

14. Schweitzer A, Horn J, Mikolajczyk RT, Krause G, Ott JJ. Estimations of worldwide prevalence of chronic hepatitis $B$ virus infection: a systematic review of data published between 1965 and 2013. The Lancet. 2015;386:1546-1555.

15. Lurie Y, Webb M, Cytter-Kuint R, Shteingart S, Lederkremer GZ. Non-invasive diagnosis of liver fibrosis and cirrhosis. World $\mathrm{J}$ Gastroenterol. 2015;21:11567-11583.

16. Behal R, Jain R, Behal KK, Dhole TN. Variation in the host $A B O$ blood group may be associated with susceptibility to hepatitis C virus infection. Epidemiol Infect. 2010;138:1096-1099.

17. Naeini $A E$, Mojtaba $R$, Naeini SE. Chronic viral hepatitis and their relation to $A B O$ blood groups and rhesus (Rh) factor. Med Case Stud. 2010;1:5-7.

18. Shavakhi A, Hajalikhani M, Minakari M, Norian A, Riahi R, Azarnia M, Liaghat $\mathrm{L}$. The association of non-O blood group and severity of liver fibrosis in patients with chronic hepatitis C infection. J Res Med Sci. 2012;17:466-469.

19. Poujol-Robert A, Boelle PY, Wendum D, Poupon R, Robert A. Association between $\mathrm{ABO}$ blood group and fibrosis severity in chronic hepatitis C infection. Dig Dis Sci. 2006;51:1633-1636.

20. Salduz ZIY, Çetin G, Karatoprak C, Özder A, Bilginç M, Gültepe I, Gül Ö. ABO and Rh Blood Group Distribution in Istanbul Province (Turkey). İstanbul Med J. 2015;16:98-100.

21. Lewkonia R, Finn R. ABO blood group distribution in serum hepatitis. BMJ. 1969;3:268-269.

22. Emeribe A, Ejezie G. ABO blood groups distribution in relation to hepatitis B surface antigen and the presence of lipoidophil antibodies. East Afr Med J. 1992;69:146-148.

23. Siransy LK, Nanga ZY, Zaba FS, Tufa NY, Dasse SR. ABO/ Rh Blood Groups and Risk of HIV Infection and Hepatitis B Among Blood Donors of Abidjan, Cote D'ivoire. Eur J Microbiol Immunol (Bp). 2015;5:205-209.

24. Lao TT, Sahota DS, Chung MK, Cheung TK, Cheng YK, Leung TY. Maternal $A B O$ and rhesus blood group phenotypes and hepatitis B surface antigen carriage. J Viral Hepat. 2014;21:818823.

25. Aljoani OAA, Al-Hayani NN, Mohammed MJ. The infection with $\mathrm{HBV}$ and $\mathrm{HCV}$ and their relationship to $\mathrm{ABO}$ blood group among blood donors. J Fac Med Baghdad. 2012;54:52-56.

26. Pourhassan A. Association between $A B O$ blood/rhesus grouping and hepatitis B and C: a case-control study. Pak J Biol Sci. 2014;17:868-871. 
27. Wang DS, Chen DL, Ren C, Wang ZQ, Qiu MZ, Luo HY, Zhang DS, Wang $\mathrm{FH}$, Li $\mathrm{YH}, \mathrm{Xu} \mathrm{RH}$. ABO blood group, hepatitis $B$ viral infection and risk of pancreatic cancer. Int $\mathrm{J}$ Cancer. 2012;131:461-468.

28. Franchini $M$, Bonfanti C. Evolutionary aspects of $A B O$ blood group in humans. Clinica Chimica Acta. 2015;444:66-71.

29. Tufano A, Coppola A, Nardo A, Bonfanti C, Crestani S, Cerbone AM, Franchini M. Non-O blood group as a risk factor for cerebral vein thrombosis. Thromb Haemost. 2013;110:197-199.

30. Hazendonk H, Lock J, Mathôt R, Meijer K, Peters M, Larosvan Gorkom BA, van der Meer FJ, Driessens $\mathrm{MH}$, Leebeek FW, Fijnvandraat K, Cnossen MH. Perioperative treatment of hemophilia A patients: Blood group $\mathrm{O}$ patients are at risk of bleeding complications. J Thromb Haemost. 2016;14:468-478.
31. Zhou $Y$, Zhou Q, Lin $Q$, Chen R, Gong Y, Liu Y, Yu M, Zeng B, Li K, Chen R, Li Z. Evaluation of risk factors for extrahepatic cholangiocarcinoma: $A B O$ blood group, hepatitis $B$ virus and their synergism. Int J Cancer. 2013;133:1867-1875.

32. Gates MA, Wolpin BM, Cramer DW, Hankinson SE, Tworoger SS. ABO blood group and incidence of epithelial ovarian cancer. Int J Cancer. 2011;128:482-486.

33. Blackwell CC, Dundas S, James VS, Mackenzie DA, Braun JM, Alkout AM, Todd WT, Elton RA, Weir DM. Blood group and susceptibility to disease caused by Escherichia coli O157. J Infect Dis. 2002;185:393-396.

34. Jang $H B$, Kim SG, Lee $A J$, Suh $H S$, Jeon $C H$, Ahn $H S$. The relationship between $A B O$ blood group phenotypes and seroprevalence of infectious disease in Korea. Korean J Blood Transfus. 2014;25:113-122 